\title{
Changes in finfish community structure associated with an offshore fishery closed area on the Scotian Shelf
}

\author{
Jonathan A. D. Fisher ${ }^{1}$, Kenneth T. Frank ${ }^{2, *}$ \\ ${ }^{1}$ Department of Biology, Life Science Centre, Dalhousie University, 1355 Oxford Street, Halifax, Nova Scotia B3H 4J1, Canada \\ ${ }^{2}$ Department of Fisheries and Oceans, Marine Fish Division, Bedford Institute of Oceanography, PO Box 1006, Dartmouth, \\ Nova Scotia B2Y 4A2, Canada
}

\begin{abstract}
In 1987 a large area $\left(\sim 13700 \mathrm{~km}^{2}\right)$ associated with 2 offshore banks on the Scotian Shelf (Nova Scotia, Canada) was closed to commercial trawling for groundfish in order to protect the juvenile stages of haddock Melanogrammus aeglefinus from discarding. We assessed possible changes in the finfish community structure before and after the closure. Species abundance data collected annually since 1970 were subjected to multivariate analyses such as cluster analysis and a randomization/permutation test. Finfish community composition was significantly different after the implementation of the closure, and several species contributed to the post-closure difference including herring Clupea harengus, winter flounder Pseudopleuronectes americanus and redfish Sebastes sp., which showed dramatic increases in abundance. Haddock was the dominant species throughout the entire period. These findings suggest that several members of the finfish community benefited from the area closure. However, community structure in a reference area that has never been closed to fishing (Browns Bank) became more similar to the community structure in the closed area, contrary to our expectations. We provide support for the hypothesis that the dynamics of the Browns Bank area finfish community are coupled to the closed area through spillover based on several lines of inquiry, including positive relationships between abundance and area occupied of the dominant species and non-contemporaneous increases in species abundance between the closed area and the Browns Bank area with lags ranging from 1 to 3 yr. This study argues that establishment of fishery closures is likely to have positive benefits to the component species at both local and regional scales; however, the time-scale for such changes appears to be relatively long in comparison to tropical systems.
\end{abstract}

KEY WORDS: Marine-protected area $\cdot$ MPA $\cdot$ Finfish community structure $\cdot$ Spillover $\cdot$ Marine conservation · Multivariate statistics · Biodiversity

Resale or republication not permitted without written consent of the publisher

\section{INTRODUCTION}

The elimination of fishing mortality on marine populations through the use of year-round area closures is a current fishery conservation strategy analogous to marine-protected areas (MPAs). Because permanence is not normally a feature of fishery closed areas, and

\footnotetext{
${ }^{*}$ Corresponding author. E-mail: frankk@mar.dfo-mpo.gc.ca
}

such closures are often directed at a specific management objective, they differ from legislated MPAs (Jamieson \& Levings 2001). The single-species conservation objectives associated with area closures, particularly in north temperate marine systems, have not always been met (Horwood et al. 1998, Frank et al. 2000, Murawski et al. 2000, Pastoors et al. 2000). Examinations of the potential changes in finfish diversity and community structure have not been pursued (but see Piet \& Rijnsdorp 1998). Conversely, in south 
temperate and tropical regions where MPAs have a longer history, community level analyses are more common (Roberts \& Polunin 1991, Jennings et al. 1996, Wantiez et al. 1997, Russ \& Alcala 1998, Babcock et al. 1999, McClanahan \& Arthur 2001). This difference is likely to be due to disparate management strategies in these regions. In north temperate areas data-intensive, single-species management approaches and analyses have dominated, while in tropical and south temperate areas multi-species management has been accepted as necessary and therefore both multi-species analyses and conservation practices are more common (Roberts \& Polunin 1993, Bohnsack \& Ault 1996).

The use of year-round marine closed areas has increased in recent years throughout the world, based largely on positive outcomes associated with closed areas in tropical and temperate nearshore areas. These positive results have increased confidence in the application of MPAs with many perceived benefits to society. Numerous evaluations of MPAs report dramatic improvements in species richness, population density, individual fish size, and/or total biomass (Roberts \& Polunin 1991, Jennings et al. 1996, Wantiez et al. 1997, Russ \& Alcala 1998, Babcock et al. 1999, McClanahan \& Arthur 2001). Support has also been provided for species spillover to adjacent areas (McClanahan \& Mangi 2000, Roberts et al. 2001), which has been hypothesised to occur following the establishment of such areas (Bohnsack \& Ault 1996, Russ \& Alcala 1996, Jennings 2000). Recently trends of multiple sites have been compiled and reviewed (Côté et al. 2001, NCEAS 2001, Halpern 2002). These reviews conclude that MPAs result in rapid, positive, accumulative effects on biodiversity, with the expectation of similar responses in other areas following their establishment. This may not be a valid assumption for continental shelf abundance or diversity, as differences in the lifestyles (especially home range) of many marine fish between offshore north temperate regions and near shore temperate or tropical regions exist (FSBI 2001).

Recognising the need to evaluate hypotheses generated through the study of communities with different lifestyles and the restrictive nature of previous singlespecies analyses in north temperate offshore closed areas, the current study focuses on finfish community analyses in a north temperate offshore environment, specifically the Scotian Shelf. As north temperate fisheries regulation looks to move from single-species to ecosystem-based management, analyses at the community level are increasingly required. The objective of this study was 2-fold: (1) to determine whether measurable changes in finfish community structure occurred after the imposition of a large offshore marine fishery closure; and (2) to evaluate the degree to which changes in the closed area were uniquely confined to that area by comparison to an appropriate fished area.

The Emerald/Western Bank closed area encompasses an area of $\sim 13700 \mathrm{~km}^{2}$ (roughly 2.5 times the area of Prince Edward Island, Canada) surrounding 2 offshore banks (<92 m depth) and a mid-depth area (92 to $183 \mathrm{~m}$ depth) on the central Scotian Shelf (Fig. 1). A mixture of Sable Island sand and gravel covers the bank and mid-depth portions, with areas classified as principally sand or principally gravel in complex arrangements (King 1970). The area is one of the dominant spawning grounds for haddock Melanogrammus aeglefinus in the Northwest Atlantic (Page \& Frank 1989), and research vessel surveys indicated that the area contains a large number of 0 to 2 yr old haddock, distinguishing it as a nursery area for this population (Frank \& Simon 1998). Due to the dominance of both juvenile and adult haddock in this area, it had been targeted as a lucrative offshore fishing zone.

The chronology of the closed area began in 1987 when the area was closed year-round to trawling (mobile gear) in an attempt to protect juvenile haddock from previously high levels of discarding (see detailed review in Frank et al. 2000). At the time, delineation of the area was based on research vessel surveys and data from onboard fisheries observers, both spanning multiple years (Fanning et al. 1987). A fixed gear fishery directed at haddock remained and expanded in the nursery area until 1993, as it was believed that fixed gear would be more selective for older age classes, thereby affording protection to juveniles and conserving the future of the haddock stock. This partial closure scenario did not afford the haddock stock adequate protection given the overall management program, and since 1993 no fishery directed at finfish has been allowed within the closed area. Due to concurrent collapses in haddock and Atlantic cod Gadus morhua stocks within the larger NAFO (Northwest Atlantic Fisheries Organization) Division 4VW (includes areas $4 \mathrm{Vn}, 4 \mathrm{Vs}$, and 4W) (Fig. 1), no directed fishery for these 2 species has been permitted since 1994 in this area.

In a recent analysis of the response of the haddock population to the closure, Frank et al. (2000) found that based on research vessel survey data up to 1997, stock recovery had not been realised. Likewise, other potential benefits including increased recruitment and rebuilding of the spawning stock biomass were not observed. Their study did, however, show that both American plaice Hippoglossoides platessoides and winter flounder Pseudopleuronectes americanus increased dramatically during the post-closure period (Frank et al. 2000). The possibility that species other than haddock have been affected through closure has not been fully examined nor has the overall finfish community composition. 


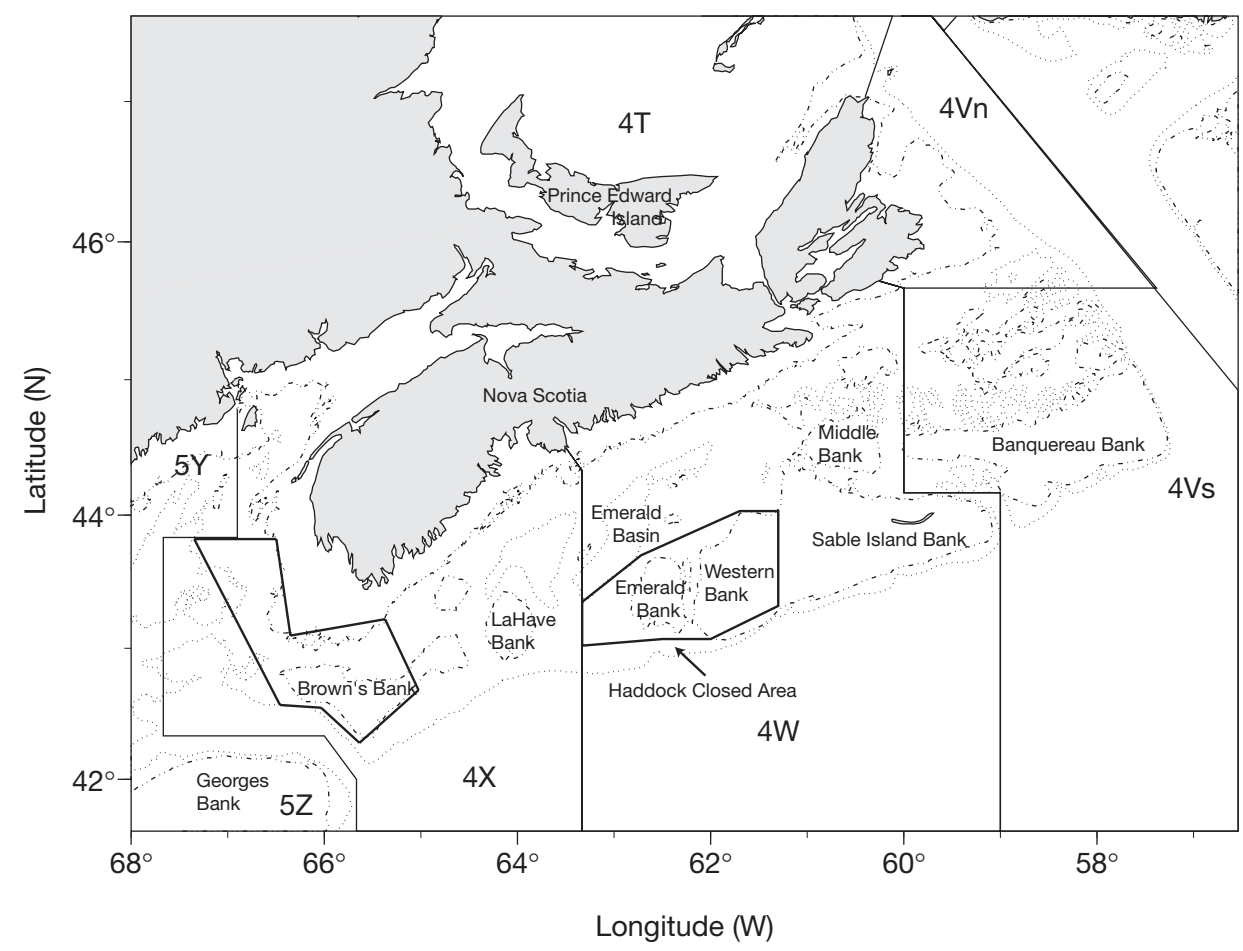

Fig. 1. Map of the Scotian Shelf with the Northwest Atlantic Fisheries Organization (NAFO) fishery statistical divisions shown. The closed area and Browns Bank reference area are outlined, with additional place names on the shelf given. The polygons surrounding the 2 areas are approximations of the actual survey strata used in the analyses

\section{MATERIALS AND METHODS}

Data collection. Data used in these analyses were compiled from 31 yr of Canadian Department of Fisheries and Oceans research vessel surveys conducted annually across the Scotian Shelf and Bay of Fundy each July (1970 to 2000). These surveys followed standardised sampling protocols using a Western IIA otter trawl and a random sampling design with areas stratified by depth in order to provide unbiased estimates of population abundance through time (see Doubleday 1981, Doubleday \& Rivard 1981). Detailed sampling of the catch provides additional information such as individual lengths and weights. The primary objective of the surveys has been to determine the distribution and abundance of exploited species. Secondarily, these surveys are conducted to gain information on nontarget species (Doubleday 1981), making the data useful for community level studies. In order to examine the finfish community, no species were excluded from the analyses on the basis of presumed species differences in capture rates. The majority of finfish collected are identified to the species level; therefore, the analysis here is limited to those samples identified to this level, with the exception of redfish Sebastes sp., which can only be accurately identified to the genus level at sea. Species included in the analyses are listed in Appendix 1.

Analyses. The historical and contemporary finfish community pattern in the area now designated as the juvenile haddock closed area was quantified using PRIMER software (Clarke \& Warwick 1994). Initially, univariate estimates of species diversity were calculated for each survey year (1970 to 2000) to determine whether or not major shifts in species richness and evenness had occurred before and after the imposition of the closed area. Hill's N1 (exponent of ShannonWiener diversity) and N2 (reciprocal of Simpson diversity) were chosen as representative indices of diversity, with the former metric sensitive to changes in rare species and the latter influenced more by changes in abundant species (Greenstreet \& Hall 1996). Because it is known that such univariate indices may conceal changes in species diversity and community structure (Dawson Shepherd et al. 1992), we undertook analyses based on multivariate methods as well. Bray-Curtis measures of similarity based on fourth-root-transformed abundance data were determined from the survey, thus forming the basis for the multivariate examinations. The Bray-Curtis similarity index has been shown to be an accurate metric of actual overlap between samples (Bloom 1981), and the transformation 
decreases the otherwise overriding influence of very abundant species (Clarke \& Warwick 1994). Based on Bray-Curtis similarity among years, a hierarchical agglomerative cluster dendrogram was developed to display the similarity in species composition between all years of the survey. The cluster groupings were evaluated in relation to the temporal changes in the management regime.

Non-parametric, permutation-based 1-way analysis of similarity (ANOSIM, Clarke 1993) was used to test the null hypothesis that within the closed area, no change in survey trawl assemblages was observed between the pre-closure (trawling impacted) and postclosure (no trawling) time periods. The pre-closure time period was based on survey data from 1970 to 1986, with post-closure similarities calculated from 1987 to 2000 .

Within the closed area, assemblage abundance was used to compare similarity among pre- and postclosure time periods. Through the similarity percentages (SIMPER) procedure, those species that on average contribute strongly to assemblages were quantified and ranked (Clarke 1993). This procedure uses the standard deviation of the Bray-Curtis dissimilarity matrix, attributed to a species, for all species pairs and compares that with the average contribution of a species to the dissimilarity. It allowed us to quantify the average contribution, by species, to the measure of dissimilarity between the pre- and post-closure time periods.

The same suite of multivariate analyses as used for the closed area was then performed on data from the Browns Bank region (Fig. 1) - a comparable area on the Scotian Shelf that has never been closed yearround to trawling. It is located near the western limit of the Scotian Shelf (in NAFO Division 4X) and is surrounded by mid-depth waters (92 to $183 \mathrm{~m}$ depths). It is a shallow ( $<92 \mathrm{~m}$ depth) offshore gravel- and sandcovered bank and is one of 2 principal spawning areas for haddock on the Scotian Shelf, the other being Emerald/Western Bank. Also, it supports an active multi-species groundfish fishery in a separate management unit involving haddock, Atlantic cod, pollock Pollachius virens, redfish and various flatfish species. The mean bottom temperature within the Browns Bank area is quite close to that within the closed area (Fig. 2), and temperature has been recognised as an environmental variable strongly associated with differences among finfish assemblages on the Scotian Shelf (Mahon \& Smith 1989). In order to evaluate an area of similar size to the closed area, Browns Bank and adjacent mid-depth areas were combined $\left(\sim 14104 \mathrm{~km}^{2}\right)$ for analysis (Fig. 1). This comparison between areas allowed a before-after-control-impact (BACI) design to be used to compare these 2 areas (Stewart-Oaten et al.
1986), which were similar in many physical and biological factors but differed markedly in management histories. This type of approach has been advocated (Carr \& Reed 1993), but also recognised as lacking in most studies of MPAs (Jennings 2000). Despite the recommendation that multiple control sites strengthen conclusions from BACI studies (Underwood 1992), examination of additional areas on the Scotian Shelf as reference sites would have been inappropriate due to known differences in physical and biological characteristics from those observed in the closed area. One factor that precluded examination of an area east of the closed area as a reference site was marked decreases in temperature over large portions of the eastern Scotian Shelf in the late 1980s and early 1990s. Such changes did not occur on the central and western Scotian Shelf (Fig. 2; also see Losier et al. 2001).

Differences between the closed area and the reference area finfish assemblages were examined through both non-metric multi-dimensional scaling (MDS) and SIMPER analyses during the pre- and post-closure time periods. MDS was based on Bray-Curtis similarity among years and areas and provided a visual display of relative similarities between all year/area combinations. SIMPER provided an estimate of the magnitude of community dissimilarity between the fished and closed areas during the pre- and post-closure periods. Further, we determined which species were the main contributors to the assemblage differences during both time periods.

Finally, in order to examine the species-specific propensity for spillover from the closed area to the reference area, species inside the closed area that exhibited post-closure increases in abundance were examined for possible positive relationships between their abundance and distribution. Distribution was expressed as the proportion of non-zero sets (sites where present) relative to the total number of sets in the survey area. Distribution was regressed against mean abundance (log transformed) of each species from only those sets where they were present. Intraspecies abundance-occupancy relationships have been described for numerous taxa, including marine fish (see review by Gaston et al. 2000). If a positive relationship exists for a species then as its abundance increases the distributional area will increase, with the potential for spillover to adjacent areas.

\section{RESULTS}

Based on species occurrence in Appendix 1, a total of 74 species (inclusive of Sebastes sp.) have been collected in these 2 areas (from 1970 to 2000). Sixty species have been collected from the closed area and 62 species from the Browns Bank area. Of the species 
listed, the majority were captured in both areas (48 species), 12 were unique to the closed area, and 14 were captured only in the Browns Bank area. The cumulative number of species (or species list) within the closed area during the pre- and post-closure periods amounted to 48 and 49 , respectively.

\section{a}
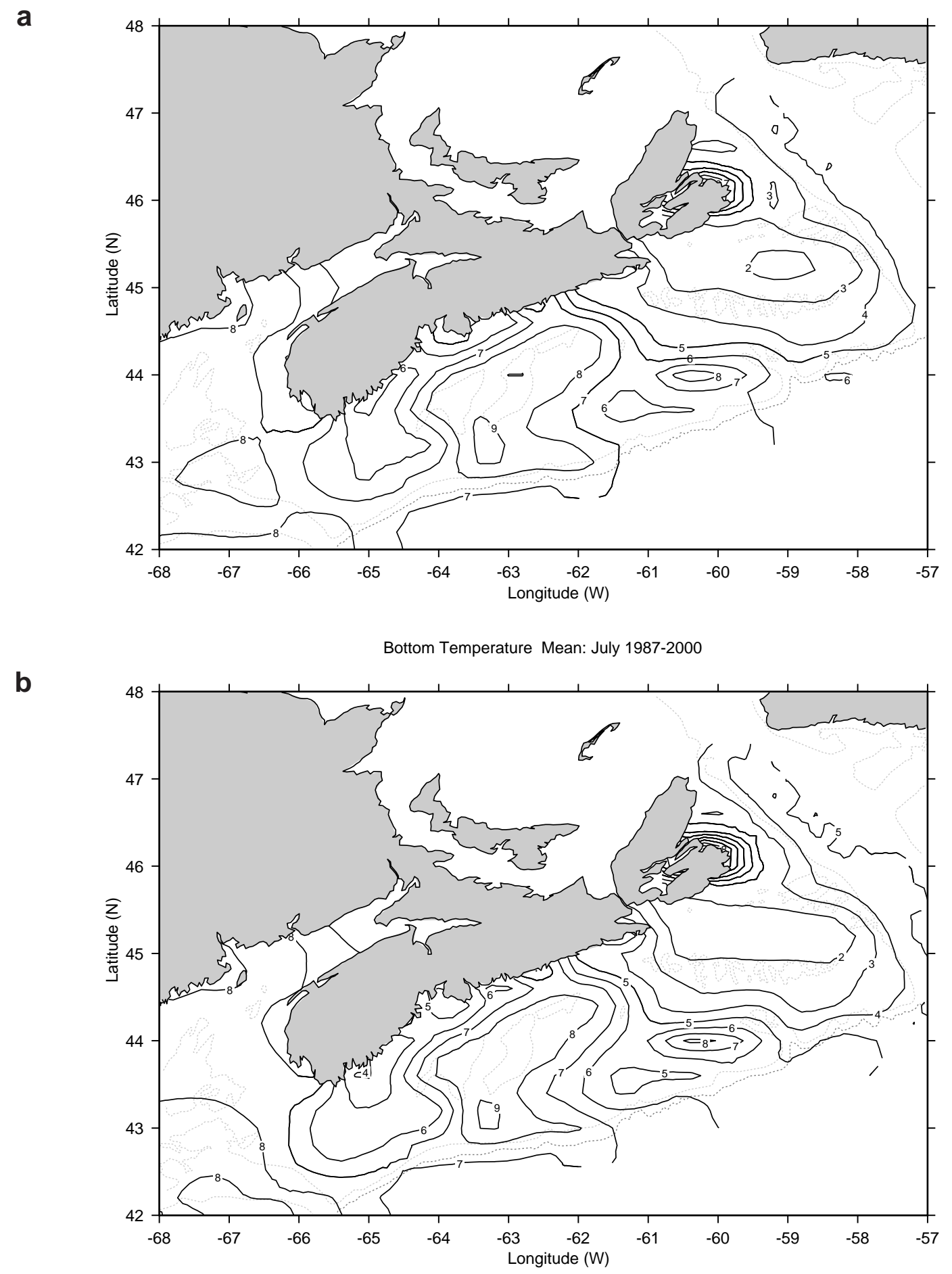

Fig. 2. Map of the Scotian Shelf showing isopleths of July bottom temperatures $\left({ }^{\circ} \mathrm{C}\right)$ averaged during (a) pre-closure and (b) postclosure time periods. In the latter period, the area influenced by cold water $\left(\leq 3^{\circ} \mathrm{C}\right)$ extended over most of the northeastern Shelf, whereas low temperatures did not penetrate the central and western Shelf 


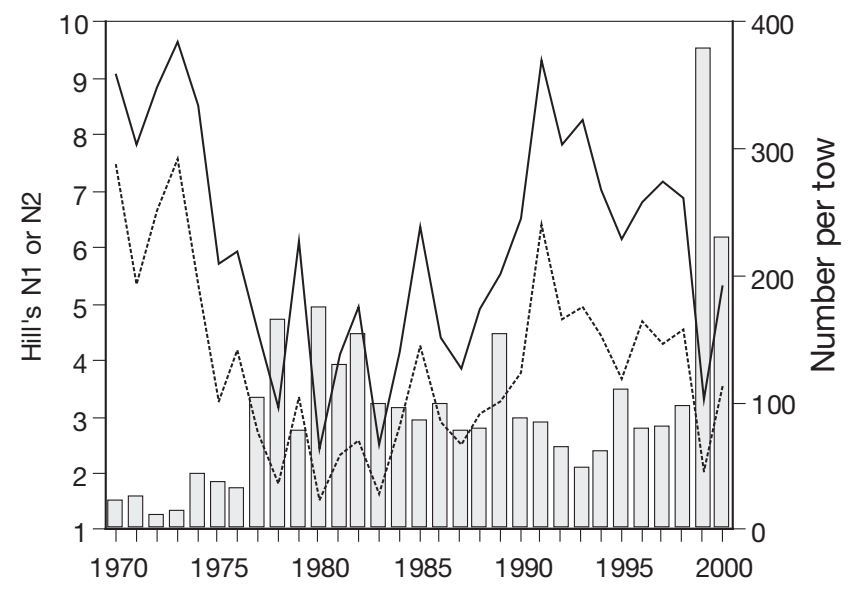

Fig. 3. Indices of species diversity for the finfish community in the closed area during 1970 to 2000. Solid line shows Hill's N1 (exponent of Shannon-Wiener diversity), dashed line is Hill's N2 (reciprocal of Simpson diversity) and histogram shows number per tow of haddock in the closed area

\section{Emerald/Western closed area}

Species diversity based on Hill's N1 was relatively low at the start of the imposition of the closed area, rose rapidly thereafter, reaching a peak in the early 1990s, and has since steadily declined (Fig. 3). During the pre-closure period, Hill's N1 was high in the early 1970s and declined to a minimum in the early 1980s. Hill's N2 paralleled the temporal pattern seen in Hill's N1 (Fig. 3). The temporal pattern of both diversity indices was strongly influenced by the abundance of the dominant species-haddock. The 2 diversity indices and haddock abundance were inversely correlated (Hill's N1: $\mathrm{r}=-0.62, \mathrm{n}=31, \mathrm{p}<0.001$; Hill's N2: $\mathrm{r}=-0.61, \mathrm{n}=31, \mathrm{p}<0.001$ ). As an indicator of community change, the chosen species diversity metrics may be overly sensitive to changes in the most abundant species. Nevertheless, comparison between pre- and post-closure means of the 2 diversity indices revealed no significant difference (Hill's N1 preand post-closure mean and $95 \% \mathrm{CI}$ : $5.79,4.59$ to 6.98 and $6.36,5.40$ to 7.31 , respectively; Hill's N2: $3.88,2.87$ to 4.88 and $3.99,3.35$ to 4.64 , respectively).

Hierarchical agglomerative clustering of finfish species composition resulted in the formation of 2 reasonably distinct clusters at the $67 \%$ similarity level (Fig. 4). These clusters of species assemblage corresponded remarkably well to the removal of trawling effort in 1987, with separation into pre- and post-closure groups. The few excep- tions to the post-closure grouping were 1982, 1985, and 1986. When survey years were grouped a priori into pre- and post-closure periods, a 1-way ANOSIM randomisation-permutation test revealed a significant difference $(R=0.545, p<0.001)$. Significant changes in the finfish community have occurred since implementation of the closed area due primarily to shifts in the relative abundance of the component species rather than to a major shift in species composition. It is notable that these differences were not apparent from the comparison of the pre- and post-closure means of the univariate species diversity metrics.

Species responsible for the changes that occurred during the post-closure period are presented through results of the SIMPER procedure. The top 6 members of the assemblage during 1970 to 1986 were haddock, silver hake Merluccius bilinearis, Atlantic cod, yellowtail flounder Limanda ferruginea, American plaice, and thorny skate Raja radiata (Table 1). These 6 species on average contributed to the majority of similarity within the pre-closure period. During the post-closure period, 8 species were required to represent a majority of the similarity within this area. These species were haddock, silver hake, herring Clupea harengus, yellowtail flounder, American plaice, Atlantic cod, pollock, and longhorn sculpin Myoxocephalus octodecemspinosus (Table 1). Many species were responsible for differences in assemblages between pre- and post-closure time periods within the closed area, although increases in herring, winter flounder, and redfish contributed most to discriminating between these time periods. Abundance anomalies for these species and 5 other species that showed increases in abundance, along with 8 species that either declined or changed only slightly since 1987, indicate that a range of population trends have occurred, with exceptional increases in winter flounder, herring, and redfish (Fig. 5). Conversely, Atlantic cod, cusk Brosme brosme, and thorny skate exhibited consistent low abundance relative to their pre-closure averages (Fig. 5).

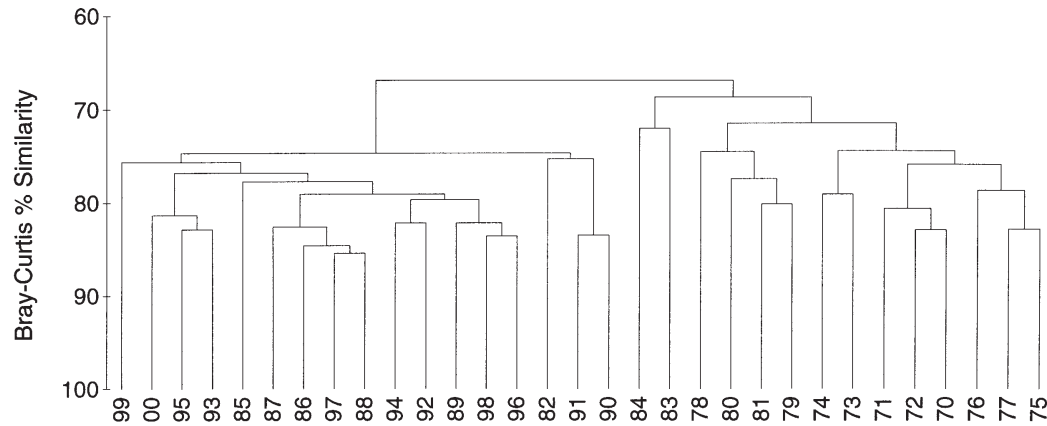

Fig. 4. Hierarchical agglomerative cluster analysis of the closed area finfish community from 1970 to 2000 based on Bray-Curtis similarity between years. Last 2 digits of each year are shown as labels 
The closed area finfish community has undergone significant change between the time periods examined. Both changes in the ranks of top species within the assemblage, and individual species abundance trends have taken place. It may make sense to attribute the clear separation of community similarity into before and after groups, and corresponding mean abundance increases in 11 of the top 14 species listed

Table 1. Closed area SIMPER summaries from pre- and post- closure survey data, showing only species contributing $\geq 3 \%$ average similarity or dissimilarity. ${ }^{*}$ Listed species contributed $<3 \%$ to the average similarity or dissimilarity

\begin{tabular}{|c|c|c|c|c|c|}
\hline \multirow[t]{2}{*}{ Species } & \multicolumn{2}{|c|}{ Pre-closure } & \multicolumn{2}{|c|}{ Post-closure } & \multirow{2}{*}{$\begin{array}{l}\text { Pre- and post- } \\
\text { closure difference } \\
\% \text { dissimilarity }\end{array}$} \\
\hline & $\begin{array}{l}\text { Mean number } \\
\text { per tow }\end{array}$ & $\begin{array}{c}\% \\
\text { similarity }\end{array}$ & $\begin{array}{l}\text { Mean number } \\
\text { per tow }\end{array}$ & $\begin{array}{c}\% \\
\text { similarity }\end{array}$ & \\
\hline Haddock & 81.5 & 13.1 & 117.6 & 10.8 & 3.1 \\
\hline Silver hake & 29.5 & 8.5 & 57.8 & 8.3 & 4.3 \\
\hline Atlantic cod & 11.5 & 8.3 & 9.4 & 5.1 & $*$ \\
\hline Yellowtail flounder & 16.3 & 7.8 & 16.1 & 6.3 & * \\
\hline American plaice & 6.6 & 6.8 & 10.2 & 5.9 & * \\
\hline Longhorn sculpin & 4.3 & 5.3 & 5.9 & 4.8 & $*$ \\
\hline Pollock & 2.9 & 4.1 & 7.3 & 5.0 & 3.2 \\
\hline White hake & 1.3 & 3.9 & 1.1 & 3.0 & ${ }^{*}$ \\
\hline Thorny skate & 3.4 & 5.6 & 0.39 & $*$ & 3.1 \\
\hline Witch flounder & 1.2 & 4.3 & 0.84 & * & $*$ \\
\hline Monkfish & 0.8 & 3.9 & 0.56 & * & * \\
\hline Halibut & 0.5 & 3.8 & 0.5 & * & $*$ \\
\hline Cusk & 0.6 & 3.6 & 0.14 & $*$ & ${ }^{*}$ \\
\hline Herring & 2.4 & $*$ & 45.4 & 6.6 & 9.1 \\
\hline Redfish & 0.4 & $*$ & 15.7 & 4.3 & 4.9 \\
\hline Red hake & 1.4 & * & 4.4 & 4.2 & 4.0 \\
\hline Winter flounder & 0.1 & * & 3.2 & 3.7 & 5.0 \\
\hline Mackerel & 1.2 & * & 4.0 & 3.2 & 3.9 \\
\hline Argentine & 6.4 & * & 6.2 & $*$ & 4.4 \\
\hline Mailed sculpin & 0.9 & $*$ & 1.3 & * & 3.3 \\
\hline Gulf stream flounder & 0.2 & $*$ & 0.9 & * & 3.1 \\
\hline Black belly rosefish & 0.1 & $*$ & 1.2 & * & 3.1 \\
\hline Spiny dogfish & 1.3 & * & 1.0 & * & 3.1 \\
\hline
\end{tabular}

\begin{tabular}{|c|c|c|c|c|c|c|c|c|c|c|c|c|c|c|}
\hline Species & 1987 & 1988 & 1989 & 1990 & 1991 & 1992 & 1993 & 1994 & 1995 & 1996 & 1997 & 1998 & 1999 & 2000 \\
\hline \multicolumn{15}{|c|}{ Winter flounder } \\
\hline \multicolumn{15}{|l|}{ Herring } \\
\hline \multicolumn{15}{|l|}{ Redfish } \\
\hline \multicolumn{15}{|l|}{ Haddock } \\
\hline \multicolumn{15}{|l|}{ Silver hake } \\
\hline \multicolumn{15}{|c|}{ Pollock } \\
\hline \multicolumn{15}{|c|}{ American plaice } \\
\hline \multicolumn{15}{|c|}{ Longhorn sculpin } \\
\hline \multicolumn{15}{|c|}{ White hake } \\
\hline \multicolumn{15}{|c|}{ Yellowtail flounder } \\
\hline \multicolumn{15}{|c|}{ Halibut } \\
\hline \multicolumn{15}{|l|}{ Witch flounder } \\
\hline \multicolumn{15}{|l|}{ Monkfish } \\
\hline \multicolumn{15}{|l|}{ Atlantic cod } \\
\hline \multicolumn{15}{|l|}{ Cusk } \\
\hline Thorny skate & & & & & & & & & & & & & & \\
\hline
\end{tabular}

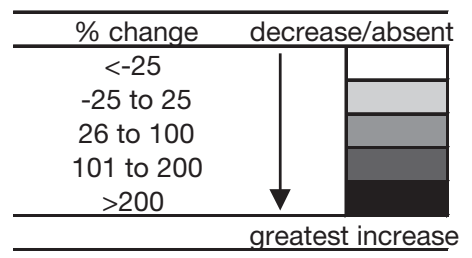

Fig. 5. Species abundance anomalies (relative to the 1970 to 1986 average) in the closed area for 8 species that generally increased relative to their abundance since closure and 8 additional common species that exhibited decreasing or variable trends. Magnitude of the change shown in key 


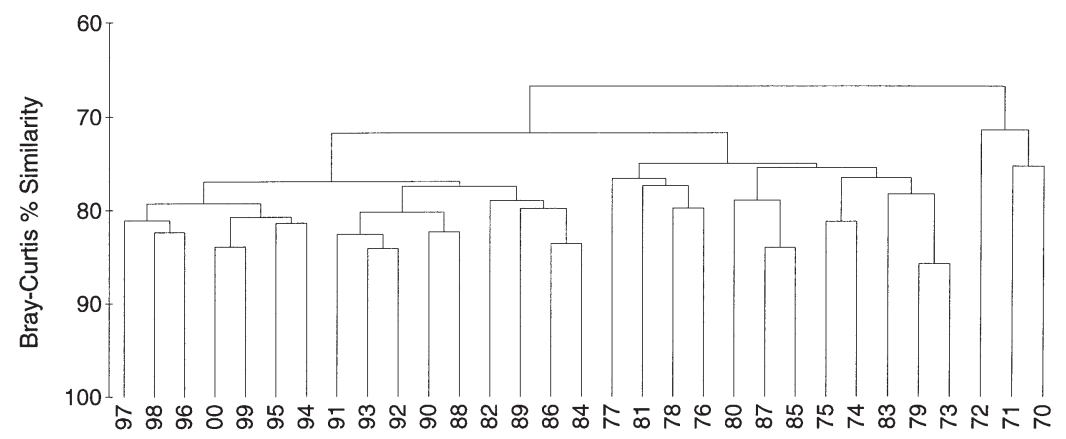

Fig. 6. Hierarchical agglomerative cluster analysis of the Browns Bank finfish community from 1970 to 2000 based on Bray-Curtis similarity between years.

Last 2 digits of each year are shown as labels

(1970 to 1972) from the later $28 \mathrm{yr}$ (Fig. 6). The next major grouping, at a somewhat higher level of similarity (72\%), separated the remaining $28 \mathrm{yr}$ into a 12 (1973 to 1981, 1983, 1985, 1987) and 16 yr $(1982,1984,1986,1988$ to 2000) block. The 1-way ANOSIM result for the Browns Bank area, however, indicated a significant difference in community composition between the preand post-closure time periods $(\mathrm{R}=0.437$, $\mathrm{p}<0.001$ ).

The results of the SIMPER analysis indicate that haddock and spiny dogfish Squalus acanthias were the top species in the Browns Bank area throughout

as discriminators (see Table 1) to the removal of trawling effort. However, in order to make this case unequivocal, it is necessary to compare the finfish community changes observed in the closed area to a suitable reference (fished) area on the Scotian Shelf.

\section{Comparison to the Browns Bank area}

Hierarchical agglomerative clustering of finfish species composition in the Browns Bank region did not result in the formation of 2 equitable clusters as was evident in the closed area. Rather, the $67 \%$ level of similarity separated only the first $3 \mathrm{yr}$ of the survey both time periods, while other species changed rank (Table 2). Increases in herring, redfish, and spiny dogfish contributed most to the Browns Bank area dissimilarity between the 2 time periods. Species abundance anomalies exhibited trends similar to many of the same species from the closed area, such as increases in herring, redfish, and winter flounder abundance, and decreased abundance of cusk and thorny skate (Fig. 7).

\section{Comparisons between areas}

The difference between the closed area and Browns Bank during the pre-closure period, based on the

Table 2. Browns area SIMPER summaries from pre- and post-closure survey data, showing only species contributing $\geq 3 \%$ average similarity or dissimilarity. ${ }^{*}$ Listed species contributes $<3 \%$ to the average similarity or dissimilarity

\begin{tabular}{|c|c|c|c|c|c|}
\hline \multirow[t]{2}{*}{ Species } & \multicolumn{2}{|c|}{ Pre-closure } & \multicolumn{2}{|c|}{ Post-closure } & \multirow{2}{*}{$\begin{array}{l}\text { Pre- and post- } \\
\text { closure difference } \\
\% \text { dissimilarity }\end{array}$} \\
\hline & $\begin{array}{l}\text { Mean number } \\
\text { per tow }\end{array}$ & $\begin{array}{c}\% \\
\text { similarity }\end{array}$ & $\begin{array}{l}\text { Mean number } \\
\text { per tow }\end{array}$ & $\begin{array}{c}\% \\
\text { similarity }\end{array}$ & \\
\hline Haddock & 70.0 & 11.18 & 102.9 & 7.78 & $*$ \\
\hline Spiny dogfish & 60.6 & 7.81 & 110.8 & 6.32 & 5.5 \\
\hline Atlantic cod & 7.8 & 6.58 & 13.6 & 4.8 & $*$ \\
\hline American plaice & 6.4 & 5.51 & 7.3 & 4.13 & $*$ \\
\hline Pollock & 11.3 & 5.38 & 20.5 & 4.41 & 3.0 \\
\hline Silver hake & 93.9 & 5.15 & 37.7 & 5.44 & 5.5 \\
\hline Redfish & 25.5 & 5.06 & 103.6 & 5.6 & 6.0 \\
\hline Yellowtail flounder & 3.4 & 4.78 & 8.2 & 4.4 & $*$ \\
\hline Longhorn sculpin & 2.8 & 4.24 & 14.0 & 4.62 & 3.1 \\
\hline White hake & 4.8 & 4.16 & 3.4 & 3.41 & $*$ \\
\hline Argentine & 6.0 & 3.52 & 39.5 & 3.36 & 4.4 \\
\hline Thorny skate & 2.6 & 4.66 & 1.0 & ${ }^{*}$ & $*$ \\
\hline Cusk & 1.8 & 4.29 & 0.44 & * & * \\
\hline Witch flounder & 1.5 & 3.75 & 1.98 & * & * \\
\hline Striped Atlantic wolffish & 1.0 & 3.39 & 1.2 & ${ }^{*}$ & $*$ \\
\hline Winter flounder & 0.6 & ${ }^{*}$ & 5.5 & 3.86 & 4.53 \\
\hline Herring & 0.6 & * & 20.3 & 3.74 & 6.5 \\
\hline Red hake & 4.4 & $*$ & 6.7 & 3.58 & 4.2 \\
\hline Mailed sculpin & 0.4 & * & 1.6 & $*$ & 3.6 \\
\hline
\end{tabular}




\begin{tabular}{|c|c|c|c|c|c|c|c|c|c|c|c|c|c|c|}
\hline \multirow{2}{*}{\multicolumn{15}{|c|}{$\begin{array}{c}\text { Species } \\
\text { Winter flounder }\end{array}$}} \\
\hline & & & & & & & & & & & & & & \\
\hline \multicolumn{15}{|l|}{ Herring } \\
\hline \multicolumn{15}{|l|}{ Redfish } \\
\hline \multirow{2}{*}{\multicolumn{15}{|c|}{$\begin{array}{l}\text { Haddock } \\
\text { Silver hake }\end{array}$}} \\
\hline \multirow{2}{*}{\multicolumn{15}{|c|}{$\begin{array}{l}\text { Silver hake } \\
\text { Pollock }\end{array}$}} \\
\hline & & & & & & & & & & & & & & \\
\hline \multicolumn{15}{|l|}{ American plaice } \\
\hline \multicolumn{15}{|l|}{ Longhorn sculpin } \\
\hline \multicolumn{15}{|c|}{ White hake } \\
\hline \multicolumn{15}{|c|}{ Yellowtail flounder } \\
\hline \multirow{2}{*}{\multicolumn{15}{|c|}{$\begin{array}{l}\text { Halibut } \\
\text { Witch flounder }\end{array}$}} \\
\hline & & & & & & & & & & & & & & \\
\hline \multicolumn{15}{|l|}{ Monkfish } \\
\hline \multicolumn{15}{|l|}{ Atlantic cod } \\
\hline Cusk & & & & & & & & & & & & & & \\
\hline Thorny skate & & & & & & & & & & & & & & \\
\hline
\end{tabular}

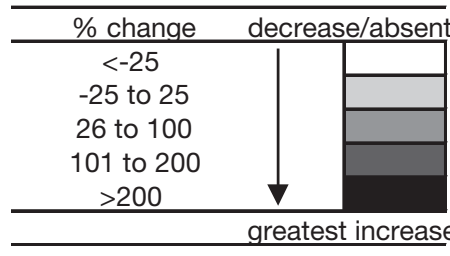

Fig. 7. Species abundance anomalies (relative to the 1970 to 1986 average) in the Browns Bank area for the same species as in Fig. 5. Magnitude of change is shown in key between-area SIMPER results, was relatively low (33\%). This result alone supports our choice of Browns Bank as a highly suitable area for comparison to the closed area. The species most responsible for the preclosure difference included spiny dogfish, redfish, and silver hake and together these species were, on aver-

Table 3. SIMPER summaries of between-areas comparison of the closed area with the Browns Bank reference area during both the pre- and post-closure periods, showing only species contributing to $\geq 3 \%$ average dissimilarity between areas. Letters in parentheses show the area where the species had higher mean abundance $(\mathrm{C}=$ closed area, $\mathrm{Br}=$ Browns Bank $)$, and bold text indicates the top 3 discriminating species in each column

\begin{tabular}{|lcc|}
\hline \multirow{2}{*}{ Species } & \multicolumn{2}{c|}{ Closed-Browns } \\
& Pre-closure & Post-closure \\
\hline Yellowtail flounder & $3.2(\mathrm{C})$ & \\
Silver hake & $\mathbf{6 . 0}(\mathrm{Br})$ & $3.3(\mathrm{C})$ \\
Red hake & $3.9(\mathrm{Br})$ & \\
Pollock & $3.7(\mathrm{Br})$ & \\
Little skate & & $3.4(\mathrm{Br})$ \\
Spiny dogfish & $\mathbf{1 0 . 9}(\mathrm{Br})$ & $\mathbf{9 . 7}(\mathrm{Br})$ \\
Mackerel & & $3.6(\mathrm{C})$ \\
Herring & $3.1(\mathrm{C})$ & $4.2(\mathrm{C})$ \\
Alewife & $4.7(\mathrm{Br})$ & $4.0(\mathrm{Br})$ \\
American shad & & $3.1(\mathrm{Br})$ \\
Redfish & $\mathbf{5 . 8}(\mathrm{Br})$ & $\mathbf{5 . 9}(\mathrm{Br})$ \\
Argentine & $4.4(\mathrm{C})$ & $\mathbf{4 . 6}(\mathrm{Br})$ \\
Average \% dissimilarity & 33 & 29 \\
& & \\
\hline
\end{tabular}

age, more abundant on Browns Bank (Table 3). During the post-closure period, the difference between the 2 areas lessened (29\%). Differences between areas during both time periods were due to differing abundance of spiny dogfish, redfish, silver hake, and argentine Argentina silus, as well as others (Table 3). Because haddock was not a discriminating species between the 2 areas, it can be inferred that the areas are similar due to their dominance by haddock. The decreasing dissimilarity (or increasing similarity) during the postclosure period was a surprising result given the contrasting fishery regimes in the 2 areas.

Another way to illustrate the growing similarity in community structure between the reference area and the closed area is through non-metric MDS. Here the MDS analysis is applied to both areas together for the 1970 to 2000 period (Fig. 8). This analysis revealed that the 2 areas form temporally dependent groupings consistent with the individual area clusters presented in Figs. $4 \& 6$. However, the convergence of the Browns Bank reference area to the closed area in recent times is notable.

One hypothesis to explain the increased similarity between the closed area and the Browns Bank area, consistent with the expectations of species responses to area closures, is that spillover of locally abundant species from the closed area may be influencing the community structure of the Browns Bank area. Several species within the closed area showed positive abundance anomalies since the closure such as herring, 
winter flounder, redfish, longhorn sculpin, and haddock (Fig. 5). These same species also increased in the Browns Bank area during the post-closure period (Fig. 7). We examined the temporal pattern of species abundance between the 2 areas using cross-correlation analysis with both positive and negative lags (from -1 to +3 yr). In all cases examined, with the exception of haddock, maximum significant correlations occurred at positive lags (Table 4). Temporal increases in the abundance of winter flounder, herring, redfish and longhorn sculpin occurred $1,3,2$, and $2 \mathrm{yr}$ later in the Browns Bank area, respectively. Temporal changes in haddock abundance between the 2 areas were concurrent (i.e. maximum correlation at 0 lag). For the 3 additional species (silver hake, American plaice, pollock) that increased in the closed area during the post-closure period, no significant correlations occurred at any lag; however, none of these species showed marked increases in the Browns Bank area. Overall, the result of the cross-correlation analysis is consistent with the spillover hypothesis for a majority of the species examined.

If spillover is indeed operating to link the 2 areas we might also expect to see a positive relationship between species density and area occupied, i.e. an expansion of range with increasing abundance. The relationship between abundance and area of distribution within the Division $4 \mathrm{~W}$ area (containing the closed area) was determined for those species that showed consistent increased abundance following the

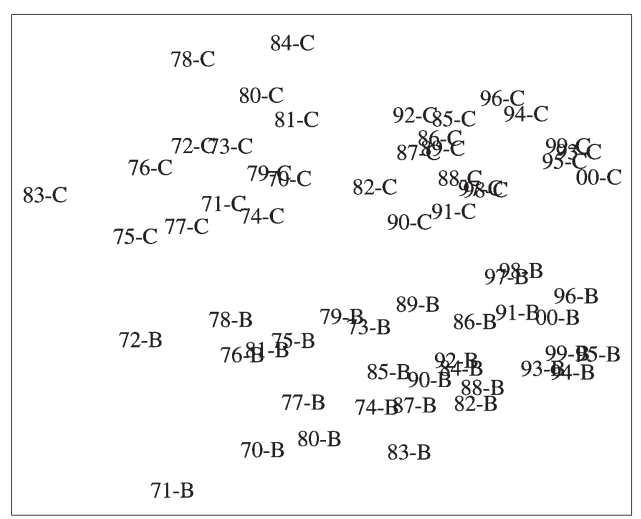

Fig 8. Non-metric multi-dimensional scaling (MDS) of the closed and reference area finfish community from 1970 to 2000. The stress level of 0.17 (stress formula 1, Kruskal \& Wish 1978) was considered sufficient for MDS to provide a useful representation of the data. For individual area trends, this plot closely matches the cluster groupings (cf. Figs. 4 \& 6). Alphanumeric labels represent year and area $(\mathrm{C}=$ closed area, $\mathrm{B}=$ Browns Bank, e.g. 99-C represents the closed area finfish community in 1999)
Table 4. Cross-correlation analysis based on species abundance time series (1970 to 2000) from the closed area and Browns Bank area at time lags from -1 to $+3 \mathrm{yr}$. For those species that increased in both the closed and reference area (winter flounder, herring, redfish, haddock and longhorn sculpin), peak correlations generally occurred at positive lags, indicative of abundance peaks in the closed area that preceded those in the Browns area. Level of significance shown as ${ }^{*} \mathrm{p}<0.05,{ }^{* *} \mathrm{p}<0.01$ and ${ }^{* * *} \mathrm{p}<0.001$

\begin{tabular}{|lccccc|}
\hline & -1 & 0 & 1 & 2 & 3 \\
\hline Winter flounder & $0.45^{*}$ & $0.54^{* *}$ & $0.78^{* * *}$ & $0.45^{*}$ & 0.23 \\
Herring & 0.34 & $0.45^{*}$ & $0.36^{*}$ & 0.28 & $0.86^{* * *}$ \\
Redfish & 0.18 & -0.03 & 0.20 & $0.49^{*}$ & -0.08 \\
Haddock & 0.32 & $0.75^{* * *}$ & $0.41^{*}$ & 0.05 & -0.14 \\
Longhorn sculpin & 0.09 & 0.17 & 0.33 & $0.38^{*}$ & 0.23 \\
Pollock & 0.28 & 0.28 & 0.13 & 0.07 & 0.01 \\
American plaice & 0.09 & 0.24 & 0.24 & 0.25 & 0.21 \\
Silver hake & 0.09 & 0.02 & 0.04 & 0.19 & 0.14 \\
n & 30 & 31 & 30 & 29 & 28 \\
& & & & & \\
\hline
\end{tabular}

closure within the closed area. Significant positive correlations between abundance and distribution were found for haddock $(r=0.84, n=31, p<0.001)$, herring $(\mathrm{r}=0.66, \mathrm{n}=28, \mathrm{p}<0.001)$, winter flounder $(\mathrm{r}$ $=0.44, \mathrm{n}=31, \mathrm{p}<0.05)$ and silver hake $(\mathrm{r}=0.38, \mathrm{n}=$ 31, $p<0.05$; Fig. 9). Non-significant, but positive correlations were obtained for redfish $(\mathrm{r}=0.15, \mathrm{n}=31$, $\mathrm{p}>0.05)$, American plaice $(\mathrm{r}=0.14, \mathrm{n}=31, \mathrm{p}>0.05)$ and longhorn sculpin $(\mathrm{r}=0.13, \mathrm{n}=31, \mathrm{p}>0.05$; Fig. 9). Finally, a non-significant correlation was obtained for pollock when 1 outlying data point was removed $(r=0.33, n=30, p>0.05)$. Collectively, these results suggest that the growing similarity in community structure observed between the 2 areas has resulted, in part, from spillover of some of the species that became locally abundant during the post-closure period in the closed area.

Additional evidence for our hypothesis was provided by removing the 5 species that increased in both areas during the post-closure period (i.e. haddock, herring, winter flounder, redfish, longhorn sculpin) and re-running the SIMPER analysis between areas. It was found that the average percent dissimilarity between areas increased from 29 to $32 \%$, which is consistent with a spillover species effect on the reference area. In other words, the 5 species had a measurable effect on the increased similarity between areas.

\section{DISCUSSION}

Although the Emerald/Western closed area was designed to protect juvenile haddock it appears to have benefited several other species. Based on the application of multivariate techniques to the finfish 

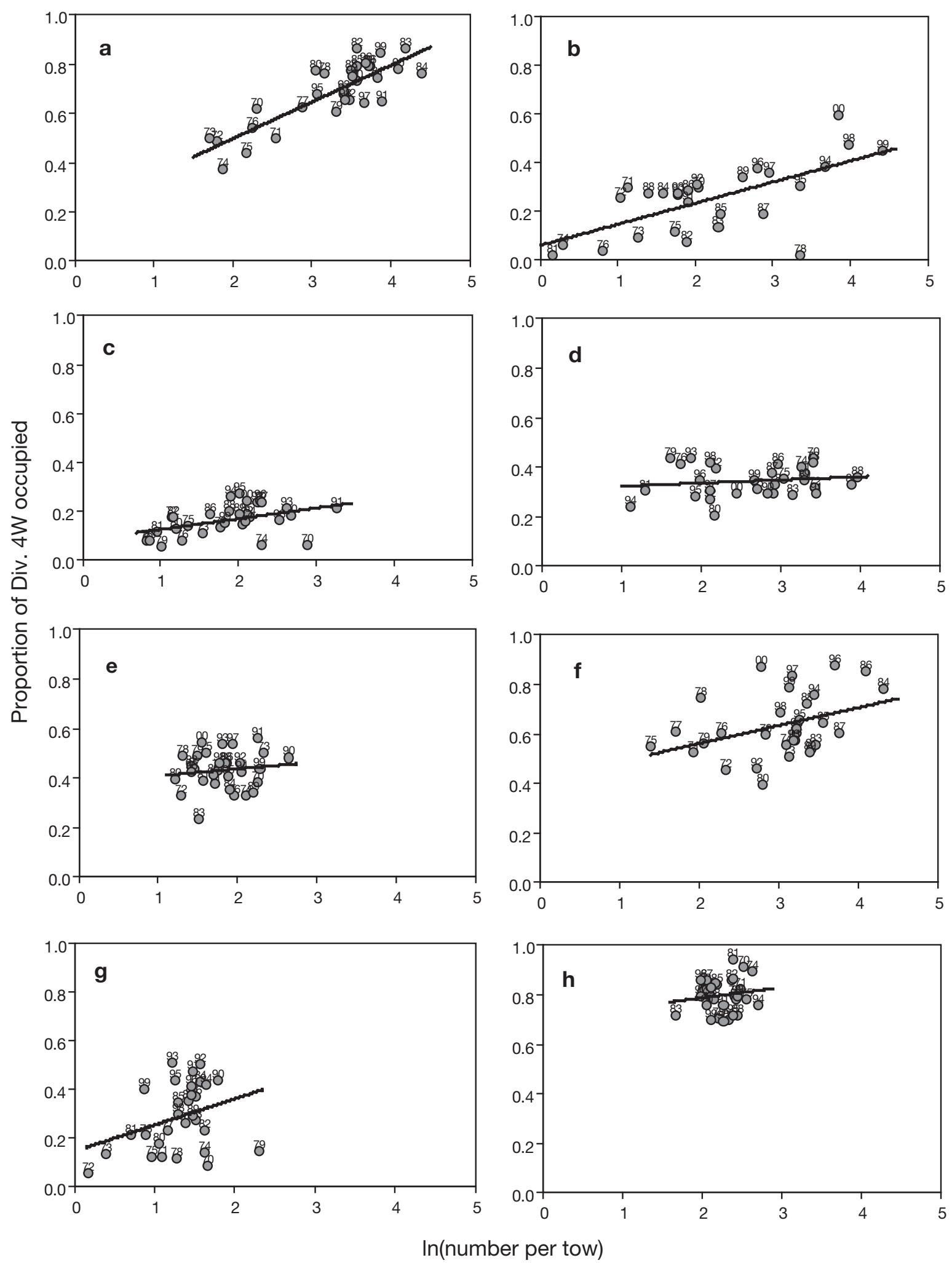

Fig. 9. Abundance-distribution relationships for 8 species that demonstrated increased abundance in the closed area. The first 5 species $(\mathrm{a}-\mathrm{e})$ increased in both the closed and Browns Bank areas since closure, while the remainder (f-h) increased only in the closed area. (a) haddock ( $\mathrm{r}=0.84, \mathrm{n}=31, \mathrm{p}<0.001)$, (b) herring $(\mathrm{r}=0.66, \mathrm{n}=28, \mathrm{p}<0.001)$, (c) winter flounder $(\mathrm{r}=0.44, \mathrm{n}=31$, $\mathrm{p}<0.05)$, (d) redfish $(\mathrm{r}=0.15, \mathrm{n}=31, \mathrm{p}>0.05)$, (e) longhorn sculpin $(\mathrm{r}=0.13, \mathrm{n}=31, \mathrm{p}>0.05)$, (f) silver hake $(\mathrm{r}=0.38, \mathrm{n}=31, \mathrm{p}<$ $0.05)$, (g) pollock $(r=0.33, n=30, p>0.05)$, (h) American plaice $(r=0.14, n=31, p>0.05)$ 


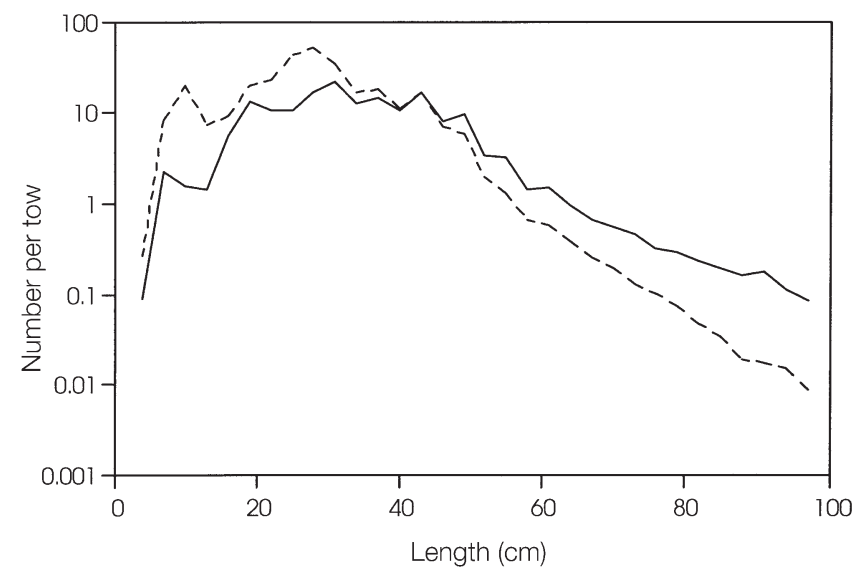

Fig. 10. Closed area, finfish community size frequency distribution before and after implementation of the closure. Data were binned into $3 \mathrm{~cm}$ size intervals from 4 to $97 \mathrm{~cm}$. Solid line represents averages from 1970 to 1986 and dashed line represents average from 1987 to 2000

survey abundance data, the closed area has undergone changes in community structure since 1987 which corresponded with the onset of the regulatory measure. Although the same 2 species (haddock and silver hake) remained, on average, most typical throughout the survey series within the closed area, changes in multiple species abundance contributed to the differences between time periods (Table 1). In addition to these differences, the multi-species similarity trends through time based on MDS illustrated that the closed area finfish community has been on a trajectory distinctly different from the pre-closure state in recent years (Fig. 8). Based on this result, the most recent survey years are the most distant from both the pre-closure years and the years immediately after the closed area's designation, with the outcome being a lack of return to the earlier historic community composition. Contributing to this trend, the ranks of some large demersal species (thorny skate, Atlantic cod, witch flounder Glyptocephalus cynoglossus, halibut Hippoglossus hippoglossus, cusk), which characterised the community in pre-closure years, have been usurped by generally smaller-bodied demersal and pelagic species (herring, redfish, red hake Urophycis chuss, winter flounder, mackerel Scomber scombrus) (Table 1). Three of these species, herring, winter flounder and redfish, demonstrate continued increases in the most recent survey years, while the former large demersal species have not shown recent increases (Fig. 5). Another way to illustrate these trends is through a comparison of community-level size frequency distributions between the 2 time periods (Fig. 10). This revealed a higher, post-closure abundance in the small size classes and lower abundance in the larger size classes relative to the pre-closure period. Abundances of the smaller sizes $(<34 \mathrm{~cm})$ were consistently higher across each size interval, ranging from 1.3 to 12.6 times higher (Fig. 10). This pattern reflects not only the increase in smallbodied demersal and pelagic species, but includes recent large year-classes of haddock produced in 1998, 1999 and 2000 (Frank et al. 2001). Through time, it is expected that these year-classes will cause the length frequency distribution to shift to larger sizes.

The question of a marine system response to longterm fishing perturbation following the removal of fishing has been asked in the past without resolution (Beddington 1984). Evidence in the current examination points towards the Emerald and Western Bank finfish community having deviated from the structure that supported a commercially viable haddock fishery. The most recent datum demonstrates that the closed area community continues on a trajectory away from the fished state (Fig. 8). However, the lack of baseline data before human impact restricts the conclusions that can be drawn from even well-studied systems with relatively long data series (Dayton et al. 1998, Steneck \& Carlton 2001). In this study, this lack of baseline data restricts tests of whether the community can be characterised as having returned to a pristine state, due to a lack of information on population densities that preceded the fishery. One clear benefit of this closure is the spatial designation of an area in which natural demographic processes and rates can take place. If this closure is maintained, this area will provide a continued view of a finfish community that is able to develop and change through natural regulation.

It was a surprising result to find that the Browns Bank area finfish community became more similar to the closed area since the latter's designation. The sharply contrasting fisheries management regimes were expected to result in divergent trends. For example, fishing effort has steadily increased in the Division $4 \mathrm{X}$ management unit while greatly reduced effort typifies Division 4VW (includes areas 4Vn, 4Vs, and 4W) due to establishment of the closed area and a fishing moratorium for Atlantic cod and haddock (Zwanenburg 2000). Similarity in community structure between these 2 areas was maintained by increases in the 3 of the top 5 discriminating species in both of these areas and dominance in both areas by haddock.

We suggested spillover from the closed area as a potential mechanism influencing the assemblage in the Browns Bank area. Results from 2 lines of inquiry tended to reinforce our position that the increasing similarity of the Browns Bank area to the closed area 

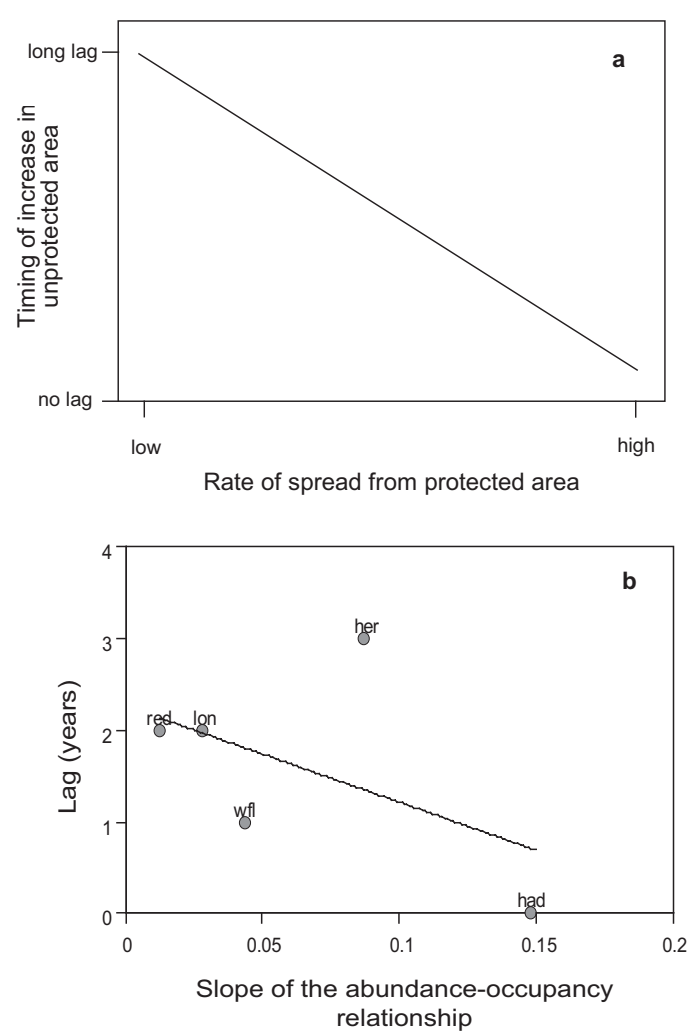

Fig. 11. (a) A schematic representation of the hypothesised relationship between the species-specific rate of spread away from the protected area, and the observed timing of increased abundance outside of the protected area. Faster spread out of the protected area is hypothesised to translate to a more rapid appearance in the unprotected area. (b) Relationship between the slope of the $\log _{e}$ (abundance)-occupancy relationship (a proxy for rate of spread) and the lag associated with the maximum correlation between the abundance time series from the closed area and Browns Bank area (for those species with significant correlations, see Table 4). Abbreviated species identifiers are: red $=$ redfish; lon = longhorn sculpin; wfl = winter flounder; her $=$ herring; had $=$ haddock

during the pre-closure period was due to spillover. We first demonstrated that the temporal increases in species abundance occurred from 1 to 3 yr later in the Browns Bank area relative to the closed area. This was true for only those species that showed increased abundance in both areas. Further, several species exhibited a positive relationship between abundance and area occupied with the slope of relationship representing an index of the rate of geographic spread. Each result on its own provides support for the spillover hypothesis. In addition, one might expect that a higher slope would translate to a shorter lag time in the species abundance response between the 2 areas (Fig. 11a). Our results are suggestive of such a relationship (Fig. 11b). It is possible that additional processes are contributing to the similarity in community structure across large geographic areas of the Scotian Shelf. One candidate mechanism is that of larval spillover (seeding) due to advection from the closed area via oceanographic currents, which are directed in a southwest direction across the shelf. Recent bio-physical models support this pattern of larval spillover for haddock, and possibly other species, to the southwest (Frank \& Brickman 2001).

It is possible that post-closure changes in finfish community structure in the closed area and on Browns Bank may reflect shelf-wide changes that are unrelated to the fishery closure. However, most of the documented changes in community composition have focused on the northeastern Scotian Shelf, where significant cooling commenced during the mid-1980s (Fig. 2) followed by increases in the abundances of several cold-water species (Frank et al. 1996). The species involved included capelin Mallotus villosus, checker eelpout Lycodes vahlii and Greenland halibut Reinhardtius hippoglossoides, none of which were present in either the closed area or the Browns Bank reference area. Also recall that our choice of the Browns Bank reference area was based, in part, on similarity of the physical environment between the 2 areas (see 'Materials and methods'). One would also expect that largescale environmental variation would manifest itself in contemporaneous increases in species abundance between the 2 areas rather than the lagged effects that were observed.

The location of marine refuges and their effects on adjacent areas are important factors in evaluating the overall spatial effects of the removal of fishing effort. As increasingly noted, the location of MPAs is key to their overall effects due to both currents influencing the transport of organisms (Carr \& Reed 1993, Allison et al. 1998, Roberts 1998) and the movements of adults (Russ \& Alcala 1996, McClanahan \& Mangi 2000, Roberts et al. 2001). In contrast to the delineation of stock boundaries, MPAs are designed to eventually provide transfer of organisms outside their bounds (Bohnsack \& Ault 1996). Jennings (2000) maintains that species that increase in protected areas and demonstrate density-dependent habitat use may emigrate outside closed areas and enhance those populations. Moreover, this pattern of density-dependent distribution provides a mechanism for the positive intraspecific abundance-occupancy relationship. Numerous temperate groundfish populations demonstrate density-dependent habitat use and therefore would be expected to demonstrate a pattern of spillover from protected areas (Jennings 2000).

In the present examination, of the 5 species that demonstrated increased abundance in the closed area and Browns Bank area, 3 conformed to the expected relationships between abundance and dis- 
tribution (Fig. 9). Redfish and longhorn sculpin increased in both areas but exhibited a somewhat weaker relationship. For some species then, this relationship may provide an outlet during times when populations in Division $4 \mathrm{~W}$ become plentiful, providing a density-dependent mechanism connecting the closed area and fished communities on and around Browns Bank.

The increased relative home range for north temperate species contributes to higher transfer rates between closed and fished areas and these high transfer rates will delay or negate the benefits for many species which are not contained in the closed area throughout their life span. The present study indicates that a very large area containing 2 banks closed to fishing on the Scotian Shelf has not led to the recovery of multiple species which declined prior to its establishment (including thorny skate, cusk, Atlantic cod, monkfish Lophius americanus, witch flounder, and halibut). The closed area may not adequately protect these species' populations throughout a significant part of their life history. It is also possible that sufficient time has not elapsed to witness their recovery. These results appear dissimilar to some of the findings from the Georges Bank closed area system (Murawski et al. 2000), where beneficial impacts on a wide range of non-target species occurred, but abundances were not quantified nor were the identities of all of the species involved reported. Because reference areas were not included in that analysis we cannot be sure of the causes associated with these apparent positive outcomes. Clearly not enough research in north temperate systems has been undertaken to draw firm conclusions about the expected direction or magnitude of effects at the community level following area closures (Auster \& Shackell 2000).

We are largely uncertain about the possible causal factors contributing to the different population trajectories within the closed area and it remains an area of investigation deserving further attention. In the meantime, we have begun to assemble some of the readily available, albeit limited, information on the life history attributes of the 16 species listed in Fig. 5 that exhibited a range of population trends since closure. The attributes compiled included egg type, maximum body size, and adult food habits. Those species that exhibited the highest increases in abundance during the closure (redfish, winter flounder and herring) had benthic (non-buoyant) or ovoviviparous egg types. This serves to limit dispersion during the early phase of the life history. In addition, these species were among the smallest in terms of maximum body size and were dependent on either pelagic or benthic food types. It is possible that the species with smaller body sizes are more likely to reside within the confines of the closed area given the general correlation between home range and body size (Roff 1988, Kramer \& Chapman 1999). The remaining species that increased after the closure had pelagic eggs, with the exception of longhorn sculpin (benthic egg type) and a wide range of maximum body sizes and food habits. The species that declined in abundance following the closure all had pelagic egg types, generally large maximum body sizes and dependency on benthic food types. While this cursory examination has pointed to some interesting patterns, it is far from complete and may remain so given the lack of available data on ageing, tagging, fecundity, rate of population increase, juvenile and adult survivorship, etc. for a majority of the species examined in this study.

A recent examination of the efficacy of fishery closed areas in the North Sea recognises that the effects on community structure and the more frequently examined stock effects within that area may be different than those reported from the tropics (FSBI 2001). They acknowledged that these dissimilarities are due to different lifestyles of the component species and differences in fishery management that together may result in longer recovery times (FSBI 2001). The examination suggests that very large closed areas (>70000 km²) will be necessary to protect many North Sea species. Modelling results from another north temperate marine system suggest a need for very large geographic areas as well, for the protection of wide-ranging species such as Northern cod (Guénette et al. 2000).

This study argues that establishment of fishery closures or MPAs is likely to have positive benefits to the component species at both a local and regional scale. The time-scale for such changes in our study was relatively long and the recovery of the target species (haddock) is only now beginning to take place (DFO 2001). This will require commitment to long-term monitoring and patience by managers and stakeholders to realise the benefits of such conservation measures.

Acknowledgements. We wish to thank the research vessels' crews and all of the Canadian Department of Fisheries and Oceans staff and volunteers who have spent many laborious days at sea during the Scotian Shelf and Bay of Fundy July groundfish survey's successful 30+ yr history. Mr. Bob Branton and Jerry Black made the data accessible through the Marine Fish Division Virtual Data Centre. Dr. Ken Drinkwater is thanked for providing temperature profiles. Mr. Jim Simon's knowledge of the survey protocols and database has been beneficial since this project's inception. We are also indebted to Drs. Nancy Shackell and Doug Swain and 4 anonymous referees for comments and constructive criticism offered on previous drafts of the manuscript. Partial support for this research was provided by the Natural Sciences and Engineering Research Council of Canada (K.T.F.). 
Appendix 1. Species collected in the closed area and reference areas during the summer groundfish survey (1970 to 2000). $\mathrm{X}$ : the species has been collected in the area

\begin{tabular}{|c|c|c|c|}
\hline \multirow[t]{2}{*}{ Common name } & \multirow[t]{2}{*}{ Scientific name } & \multicolumn{2}{|c|}{ Species collected in } \\
\hline & & Closed & Browns \\
\hline Atlantic sea poacher & Agonus decagonus & & $\mathrm{X}$ \\
\hline Alewife & Alosa pseudoharengus & $\mathrm{X}$ & $\mathrm{X}$ \\
\hline American shad & Alosa sapidissima & & $\mathrm{X}$ \\
\hline Northern sand lance & Ammodytes dubius & $\mathrm{X}$ & $\mathrm{X}$ \\
\hline Striped Atlantic wolffish & Anarhichas lupus & $\mathrm{X}$ & $\mathrm{X}$ \\
\hline Yellowfin bass & Anthias nicholsi & $\mathrm{X}$ & \\
\hline Argentine & Argentina silus & $\mathrm{X}$ & $\mathrm{X}$ \\
\hline Atlantic hookear sculpin & Artediellus atlanticus & $\mathrm{X}$ & $\mathrm{X}$ \\
\hline Arctic hookear sculpin & Artediellus uncinatus & $\mathrm{X}$ & $\mathrm{X}$ \\
\hline Alligatorfish & Aspidophoroides monopterygius & $\mathrm{X}$ & $\mathrm{X}$ \\
\hline Arctic alligatorfish & Aspidophoroides olriki & & $\mathrm{X}$ \\
\hline Cusk & Brosme brosme & $\mathrm{X}$ & $\mathrm{X}$ \\
\hline Short-nose greeneye & Chlorophthalmus agassizi & $\mathrm{X}$ & $\mathrm{X}$ \\
\hline Gulf stream flounder & Citharichthys arctifrons & $\mathrm{X}$ & $\mathrm{X}$ \\
\hline Atlantic herring & Clupea harengus & $\mathrm{X}$ & $\mathrm{X}$ \\
\hline Longnose grenadier & Coelorhynchus carminatus & & $\mathrm{X}$ \\
\hline Polar sculpin & Cottunculus microps & $\mathrm{X}$ & \\
\hline Wrymouth & Cryptacanthodes maculatus & & $\mathrm{X}$ \\
\hline Lumpfish & Cyclopterus lumpus & $\mathrm{X}$ & $\mathrm{X}$ \\
\hline Atlantic batfish & Dibranchus atlanticus & $\mathrm{X}$ & \\
\hline Fourbeard rockling & Enchelyopus cimbrius & $\mathrm{X}$ & $\mathrm{X}$ \\
\hline Atlantic cod & Gadus morhua & $\mathrm{X}$ & $\mathrm{X}$ \\
\hline Witch flounder & Glyptocephalus cynoglossus & $\mathrm{X}$ & $\mathrm{X}$ \\
\hline Black belly rosefish & Helicolenus dactylopterus & $\mathrm{X}$ & $\mathrm{X}$ \\
\hline Sea raven & Hemitripterus americanus & $\mathrm{X}$ & $\mathrm{X}$ \\
\hline American plaice & Hippoglossoides platessoides & $\mathrm{X}$ & $\mathrm{X}$ \\
\hline Atlantic halibut & Hippoglossus hippoglossus & $\mathrm{X}$ & $\mathrm{X}$ \\
\hline Spatulate sculpin & Icelus spatula & & $\mathrm{X}$ \\
\hline Yellowtail flounder & Limanda ferruginea & $\mathrm{X}$ & $\mathrm{X}$ \\
\hline Monkfish & Lophius americanus & $\mathrm{X}$ & $\mathrm{X}$ \\
\hline Snake blenny & Lumpenus lumpretaeformis & $\mathrm{X}$ & $\mathrm{X}$ \\
\hline Wolf eelpout & Lycenchelys verrilli & & $\mathrm{X}$ \\
\hline Pale eelpout & Lycodes pallidus & & $\mathrm{X}$ \\
\hline Arctic eelpout & Lycodes reticulatus & & $\mathrm{X}$ \\
\hline Ocean pout & Macrozoarces americanus & $\mathrm{X}$ & $\mathrm{X}$ \\
\hline Muller's pearlsides & Maurolicus muelleri & $\mathrm{X}$ & \\
\hline Haddock & Melanogrammus aeglefinus & $\mathrm{X}$ & $\mathrm{X}$ \\
\hline Atlantic soft pout & Melanostigma atlanticum & & $\mathrm{X}$ \\
\hline Off-shore hake & Merluccius albidus & $\mathrm{X}$ & $\mathrm{X}$ \\
\hline Silver hake & Merluccius bilinearis & $\mathrm{X}$ & $\mathrm{X}$ \\
\hline Deepwater flounder & Monolene sessilicauda & $\mathrm{X}$ & \\
\hline Spotted lanternfish & Myctophum punctatum & $\mathrm{X}$ & \\
\hline Longhorn sculpin & Myoxocephalus octodecemspinosus & $\mathrm{X}$ & $X$ \\
\hline Shorthorn sculpin & Myoxocephalus scorpius & & $\mathrm{X}$ \\
\hline Northern hagfish & Myxine glutinosa & $\mathrm{X}$ & $\mathrm{X}$ \\
\hline Snipe eel & Nemichthys scolopaceus & & $\mathrm{X}$ \\
\hline Marlin-spike grenadier & Nezumia bairdi & $\mathrm{X}$ & \\
\hline Fourspot flounder & Paralichthys oblongus & $\mathrm{X}$ & $\mathrm{X}$ \\
\hline Butterfish & Peprilus triacanthus & $\mathrm{X}$ & $\mathrm{X}$ \\
\hline Sea lamprey & Petromyzon marinus & $\mathrm{X}$ & \\
\hline Rock gunnel & Pholis gunnellus & $\mathrm{X}$ & $\mathrm{X}$ \\
\hline Longfin hake & Phycis chesteri & $\mathrm{X}$ & $\mathrm{X}$ \\
\hline Pollock & Pollachius virens & $\mathrm{X}$ & $\mathrm{X}$ \\
\hline Stout beard fish & Polymixia nobilis & $\mathrm{X}$ & \\
\hline Winter flounder & Pseudopleuronectes americanus & $\mathrm{X}$ & $\mathrm{X}$ \\
\hline Little skate & Raja erinacea & $\mathrm{X}$ & $\mathrm{X}$ \\
\hline Round skate & Raja fyllae & $\mathrm{X}$ & \\
\hline Barndoor skate & Raja laevis & $\mathrm{X}$ & $\mathrm{X}$ \\
\hline Winter skate & Raja ocellata & $\mathrm{X}$ & $\mathrm{X}$ \\
\hline
\end{tabular}


Appendix 1 (continued)

\begin{tabular}{|c|c|c|c|}
\hline \multirow[t]{2}{*}{ Common name } & \multirow[t]{2}{*}{ Scientific name } & \multicolumn{2}{|c|}{ Species collected in } \\
\hline & & Closed & Browns \\
\hline Thorny skate & Raja radiata & $\mathrm{X}$ & $\mathrm{X}$ \\
\hline Smooth skate & Raja senta & $\mathrm{X}$ & $\mathrm{X}$ \\
\hline Mackerel & Scomber scombrus & $\mathrm{X}$ & $\mathrm{X}$ \\
\hline Atlantic saury & Scomberesox saurus & $\mathrm{X}$ & $\mathrm{X}$ \\
\hline Windowpane & Scophthalmus aquosus & $\mathrm{X}$ & \\
\hline Redfish (unseparated) & Sebastes sp. & $\mathrm{X}$ & $\mathrm{X}$ \\
\hline Spiny dogfish & Squalus acanthias & $\mathrm{X}$ & $\mathrm{X}$ \\
\hline Boa dragonfish & Stomias boa ferox & & $\mathrm{X}$ \\
\hline Cunner & Tautogolabrus adspersus & $\mathrm{X}$ & \\
\hline Mailed sculpin & Triglops murrayi & $\mathrm{X}$ & $\mathrm{X}$ \\
\hline Radiated shanny & Ulvaria subbifurcata & $\mathrm{X}$ & $\mathrm{X}$ \\
\hline Red hake & Urophycis chuss & $\mathrm{X}$ & $\mathrm{X}$ \\
\hline Spotted hake & Urophycis regius & & $\mathrm{X}$ \\
\hline White hake & Urophycis tenuis & $\mathrm{X}$ & $\mathrm{X}$ \\
\hline \multirow[t]{2}{*}{ American John Dory } & Zenopsis ocellata & $\mathrm{X}$ & $\mathrm{X}$ \\
\hline & Total number collected & 60 & 62 \\
\hline
\end{tabular}

\section{LITERATURE CITED}

Allison GW, Lubchenco J, Carr MH (1998) Marine reserves are necessary but not sufficient for marine conservation. Ecol Appl 8:S79-S92

Auster PJ, Shackell NL (2000) Marine protected areas for the temperate and boreal Northwest Atlantic: the potential for sustainable fisheries and conservation of biodiversity. Northeast Nat 7:419-434

Babcock RC, Kelly S, Shears NT, Walker JW, Willis TJ (1999) Changes in community structure in temperate marine reserves. Mar Ecol Prog Ser 189:125-134

Beddington JR (1984) The response of multispecies systems to perturbations. In: May RM (ed) Exploitation of marine communities. Springer-Verlag, Berlin, p 209-225

Bloom SA (1981) Similarity indices in community studies: potential pitfalls. Mar Ecol Prog Ser 5:125-128

Bohnsack JA, Ault JS (1996) Management strategies to conserve marine biodiversity. Oceanography 9:73-82

Carr MH, Reed DC (1993) Conceptual issues relevant to marine harvest refuges: examples from temperate reef fishes. Can J Fish Aquat Sci 50:2019-2028

Clarke KR (1993) Non-parametric multivariate analyses of changes in community structure. Aust J Ecol 18:117-143

Clarke KR, Warwick RM (1994) Change in marine communities: an approach to statistical analysis and interpretation. Bourne Press Limited, Bournemouth

Côté IM, Mosqueira I, Reynolds JD (2001) Effects of marine reserve characteristics on the protection of fish populations: a meta-analysis. J Fish Biol 59(Suppl A):178-189

Dawson Shepherd AR, Warwick RM, Clarke KR, Brown BE (1992) An analysis of fish community responses to coral mining in the Maldives. Environ Biol Fish 33:367-380

Dayton PK, Tegner MJ, Edwards PB, Riser KL (1998) Sliding baselines, ghosts, and reduced expectations in kelp forest communities. Ecol Appl 8:309-322

DFO (Department of Fisheries and Oceans, Canada) (2001) Haddock on the eastern Scotian Shelf (Div. 4TVW). DFO Sci Stock Status Rep A3-06 (2001), Maritimes Provinces Regional Advisory Process, DFO, Dartmouth (also available at: www.dfo-mpo.gc.ca/csas)
Doubleday WG (1981) Manual on groundfish surveys in the Northwest Atlantic. NAFO Scientific Councel Studies 2, Northwest Atlantic Fisheries Organization, Dartmouth

Doubleday WG, Rivard D (1981) Bottom trawl surveys. Can Spec Publ Fish Aquat Sci 58

Fanning P, Zwanenburg KCT, Showell MA (1987) Haddock nursery closed areas: delineation and impact. CAFSAC Res Doc 87/59, Canadian Atlantic Fisheries Scientific Advisory Committee, Dartmouth

Frank KT, Brickman D (2001) Contemporary management issues confronting fisheries science. J Sea Res 45:173-187

Frank KT, Simon JE (1998) An evaluation of the Emerald/ Western Bank juvenile haddock closed area. CSAS Res Doc 98/53, Canadian Stock Assessment Secretariat, DFO, Ottawa

Frank KT, Carscadden JE, Simon JE (1996) Recent excursions of capelin (Mallotus villosus) to the Scotian Shelf and Flemish Cap during anomalous hydrographic conditions. Can J Fish Aquat Sci 53:1473-1486

Frank KT, Shackell NL, Simon JE (2000) An evaluation of the Emerald/Western Bank juvenile haddock closed area. ICES J Mar Sci 57:1023-1034

Frank KT, Mohn RK, Simon JE (2001) Assessment of the status of Div. 4TVW Haddock: 2000. CSAS Res Doc 2001/100, DFO, Ottawa (also available at: www.dfo-mpo. gc.ca/csas)

FSBI (Fisheries Society of the British Isles) (2001) Marine protected areas in the North Sea. Briefing Paper 1. Fisheries Society of the British Isles, Granta Information Systems, Cambridge

Gaston KJ, Blackburn TM, Greenwood JJD, Gregory RD, Quinn RM, Lawton JH (2000) Abundance-occupancy relationships. J Appl Ecol 37(Suppl 1):39-59

Greenstreet SPR, Hall SJ (1996) Fishing and the ground-fish assemblage structure in the north-western North Sea: an analysis of long-term and spatial trends. J Anim Ecol 65: 577-598

Guénette S, Pitcher TJ, Walters CJ (2000) The potential of marine reserves for the management of northern cod in Newfoundland. Bull Mar Sci 66:831-852

Halpern B (2002) The impact of marine reserves: do marine 
reserves work and does reserve size matter? Ecol Appl (in press)

Horwood JW, Nichols JH, Milligan S (1998) Evaluation of closed areas for fish stock conservation. J Appl Ecol 35: 893-903

Jamieson GS, Levings CO (2001) Marine protected areas in Canada-implications for both conservation and fisheries management. Can J Fish Aquat Sci 58:138-156

Jennings S (2000) Patterns and prediction of population recovery in marine reserves. Rev Fish Biol Fish 10: $209-231$

Jennings S, Marshall SS, Polunin NVC (1996) Seychelles' marine protected areas: comparative structure and status of reef fish communities. Biol Conserv 75:201-209

King LH (1970) Surficial geology of the Halifax-Sable Island map area. Marine Science Branch, Marine Science Paper 1, Department of Energy, Mines and Resources, Ottawa

Kramer DL, Chapman MR (1999) Implications of fish home range size and relocation for marine reserve function. Environ Biol Fish 55:65-79

Kruskal JB, Wish M (1978) Multidimensional Scaling. Sage Publications, Beverly Hills, CA

Losier R, Page F, McCurdy P, McRuer J (2001) Overview of 2000 hydrographic sampling effort and near-bottom water temperature and salinity conditions during the Canadian research vessel groundfish summer surveys conducted on the Scotian Shelf and in the Bay of Fundy (4VWX). DFO Atl Fish Res Doc 2001/062, DFO, Ottawa

Mahon R, Smith RW (1989) Demersal fish assemblages on the Scotian Shelf, Northwest Atlantic: spatial distribution and persistence. Can J Fish Aquat Sci 46 (Suppl 1): $134-152$

McClanahan TR, Arthur R (2001) The effect of marine reserves and habitat on populations of East African coral reef fishes. Ecol Appl 11:559-569

McClanahan TR, Mangi S (2000) Spillover of exploitable fishes from a marine park and its effect on the adjacent fishery. Ecol Appl 10:1792-1805

Murawski SA, Brown R, Lai HL, Rago PJ, Hendrickson L (2000) Large-scale closed areas as a fishery-management tool in temperate marine systems: the Georges Bank experience. Bull Mar Sci 66:775-798

NCEAS (National Center for Ecological Analysis and Synthesis) (2001) Scientific consensus statement on marine reserves and marine protected areas. National Center for Ecological Analysis and Synthesis, University of California, Santa Barbara, CA

Editorial responsibility: Howard Browman (Contributing Editor), Storebø, Norway
Page FH, Frank KT (1989) Spawning time and egg stage duration in Northwest Atlantic haddock (Melanogrammus aeglefinus) stocks with emphasis on Georges and Browns Bank. Can J Fish Aquat Sci 46(Suppl 1):68-81

Pastoors MA, Rijnsdorp AD, Van Beck FA (2000) Effects of a partially closed area in the North Sea ('plaice box') on stock development of plaice. ICES J Mar Sci 57:1014-1022

Piet GJ, Rijnsdorp AD (1998) Changes in the demersal fish assemblage in the south-eastern North Sea following the establishment of a protected area ('plaice box'). ICES J Mar Sci 55:420-429

Roberts CM (1998) Sources, sinks, and the design of marine reserve networks. Fisheries 23:16-19

Roberts CM, Polunin NVC (1991) Are marine reserves effective in management of reef fisheries? Rev Fish Biol Fish 1: 65-91

Roberts CM, Polunin NVC (1993) Marine reserves: simple solutions to managing complex fisheries? Ambio 22: 363-368

Roberts CM, Bohnsack JA, Gell F, Hawkins JP, Goodridge R (2001) Effects of marine reserves on adjacent fisheries. Science 294:1920-1923

Roff DA (1988) The evolution of migration and some life history parameters of marine fishes. Environ Biol Fish 22: 133-146

Russ GR, Alcala AC (1996) Do marine reserves export adult fish biomass? Evidence from Apo Island, central Philippines. Mar Ecol Prog Ser 17:383-397

Russ GR, Alcala AC (1998) Natural fishing experiments in marine reserves 1983-1993: community and trophic responses. Coral Reefs 17:383-397

Steneck RS, Carlton JT (2001) Human alterations of marine communities: students beware! In: Bertness MD, Gaines $\mathrm{SD}$, Hay ME (eds) Marine community ecology. Sinauer Associates, Sunderland, MA, p 445-468

Stewart-Oaten A, Murdoch WW, Parker KR (1986) Environmental impact assessment: 'pseudoreplication' in time? Ecology 67:929-940

Underwood AJ (1992) Beyond BACI: the detection of environmental impacts on populations in the real, but variable, world. J Exp Mar Biol Ecol 161:145-178

Wantiez L, Thollot P, Kulbicki M (1997) Effects of marine reserves on coral reef fish communities from five islands in New Caledonia. Coral Reefs 16:215-224

Zwanenburg KCT (2000) The effects of fishing on demersal fish communities of the Scotian Shelf. ICES J Mar Sci 57: 503-509

Submitted: March 8, 2002; Accepted: May 24, 2002

Proofs received from author(s): July 15, 2002 